\title{
Hydranencephaly in Association with Roberts Syndrome
}

\author{
CHRIS E. U. EKONG AND BOHDAN ROZDILSKY
}

SUMMARY: A clinicopathological study in a case of Roberts syndrome (tetraphocomelia, cleft lip and palate, and phallic hypertrophy) is reported. This patient had hydranencephaly and imperforate anus, two additional congenital abnormalities so far not reported in this syndrome.

RÉSUMÉ: Nous rapportons l'étude clinico pathologique d'un cas de syndrome de Roberts (tétraphocomélie, bec de lièvre et hypertrophie phallique). Ce patient présentait également une hydranencéphalie et un anus non perforé - deax anomalies congénitales non préalablement connues dans ce syndrome.

From the Division of Neuropathology, University Hospital, Saskatoon, Canada

Reprint requests to: Dr. Chris Ekong, Department of Neurosciences, University of Saskatchewan, Saskatoon, Canada S7N 0W8.
In 1919, Dr. John Roberts described a brother and sister with tetraphocomelia, cleft lip and palate, and phallic hypertrophy. This combination of congenital abnormalities has subsequently been named Roberts syndrome. Twenty-two similar cases have been reported (Appelt et al., 1966; Holmes et al., 1972; Freeman et al., 1974).

Other congenital anomalies include cryptorchidism, patent ductus arteriosus and foramen ovale, encephalocele, polycystic kidneys, horse-shoe kidneys and deformity of base of skull and cribriform plate (Holmes et al., 1972). Two cases with hydrocephalus and one of spina bifida of lumbar vertebrae (Freeman et al., 1974) have also been reported and those surviving longer than a few weeks were all mentally retarded. We are reporting a case of Roberts syndrome with hydranencephaly and imperforate anus as additional developmental anomalies.

\section{CASE REPORT}

Baby $\mathrm{H}$ was the first pregnancy for an 18 year old mother. The pregnancy was uneventful. The only medications she took during the gestation were iron and calcuim tablets. She was delivered by caesarean section because of fetal distress in the forty-second week of pregnancy. Hydramnios was evident at the caesarean section and a grossly abnormal baby weighing $1.5 \mathrm{~kg}$ (Figure 1) was delivered. It had a cleft lip and palate with protrusion of the premaxilla. The sex could not be determined grossly as the phallus was hypertrophied and there was no scrotum, labia, or testicles. The forearms and legs were short and emerged directly from the trunk, giving an impression of tetraphocomelia. The hands and feet were replaced with fluid-filled cystic structures. The anus was im- perforate. Marked hypertelorism was noted. The head appeared normal in size but the neck was short and stiff. The infant died a few minutes after birth. Family history revealed that the patient's mother's two sisters had no children, as they spontaneously aborted during each pregnancy. The patient's parents were not consanguineously related.

A post mortem total body radiograph (Figure 2) revealed oxycephalic calvarium. The tubular bones of the upper and lower extremities were moderately well developed, but were short compared to the body size.

\section{PATHOLOGY}

The scalp appeared normal. The skull was fairly well developed, apart from the fact that the posterior fossa was not formed at all and the parietal bones were widely separated from

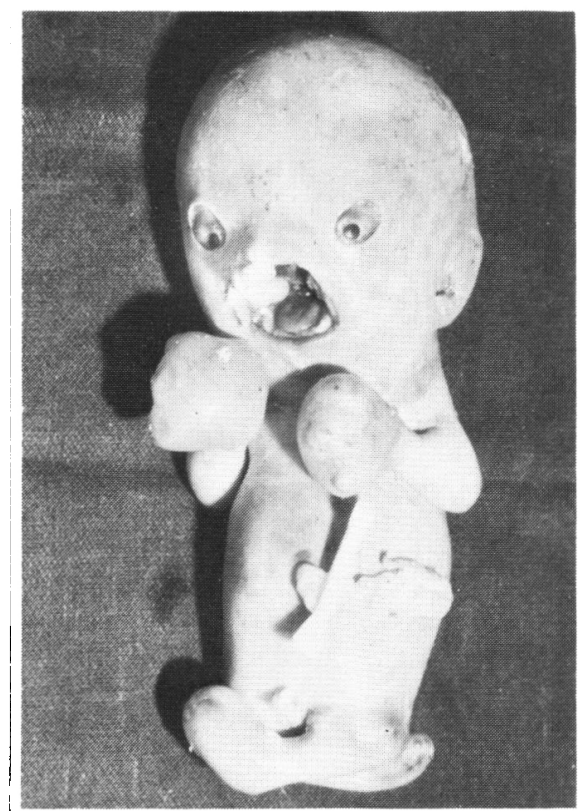

Figure 1-Photograph of the case of Roberts syndrome shortly after death. 


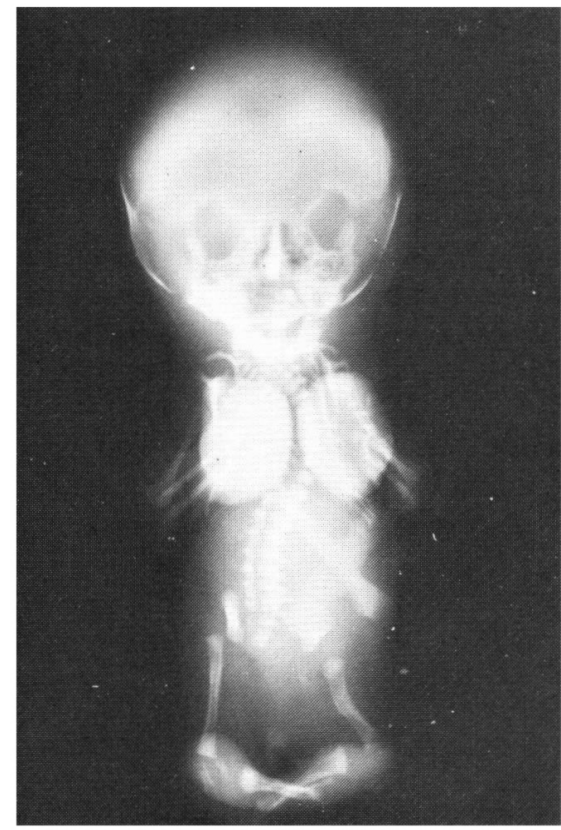

Figure 2-Total body radiograph of this case, taken shortly after death. Oxycephalic calvarium, scoliosis, and fairly well formed but short tubular bones are noted.

each other and from the frontal bone. The dura was firmly attached to the skull and underlying it was a large cyst (Figure 3 ) containing $215 \mathrm{cc}$ of clear colorless fluid. The cerebellum was not seen. The spinal cord was seen emerging from the foramen magnum and extending for about 1 $\mathrm{cm}$ into the cranium, forming the brain stem and the stalk of the cyst. A round nodule about $3 \mathrm{~mm}$ in diameter, believed to be the pituitary, was retrieved from the sella. The membranous wall of the cyst (Figure 4) (without the fluid) weighed $8 \mathrm{Gm}$.

Representative coronal sections of the membranous wall of the cyst were made. Horizontal sections of the tissue, believed to be the brain stem, and sections from the tissue from the sella, were also made. The membrane varied in thickness from $0.5 \mathrm{~mm}$ over the convexities to $3 \mathrm{~mm}$ at the base, corresponding to the hypoplastic basal ganglia and diencephalon. In most areas it consisted of a sparsely cellular leptomeninx externally, a thin cerebral tissue made up of a densely cellular outer part, and a less cellular inner part, lined in most parts by ependyma. The cells of the cerebral tissue were poorly differentiated and neurons could not be identified (Figure 5).

The histological appearance of the most distal part of the brain stem was consistent with that of embryonic midbrain. The aqueduct was well formed and lined by ependymal cells. The parenchyma was made up of poorly differentiated glia. The more proximal part of the brain stem was compatible with the pons and medulla. Here, although the parenchyma was poorly differentiated, a few neurons, representing cranial nerve nuclei, were identified. The ependymal lining of the central canal of the medulla and the 4th ventricle were well formed. The tissue from the sella was made up of epitheliallike cells arranged in glandular pattern with normal proportion of eosinophilic cells, and was compatible with the pituitary gland. The diagnosis of hydranencephaly was made.

Additional findings at autopsy included right renal and ureteric agenesis. No testicular, ovarian, uterine or vaginal structures were identifiable. The thyroid, thymus, heart and great vessels, lungs, esophagus, intestines, liver, gallbladder and spleen were all normal. The urinary bladder appeared grossly normal, but showed slight eosinophilic cystitis.

\section{COMMENT}

The syndrome of tetraphocomelia, cleft lip and palate, and phallic hypertrophy (Roberts syndrome) is a rare congenital abnormality (Freeman et al., 1974). Most of the reported cases have been sporadic, but Holmes et al. (1972) and Freeman et al. (1974) have proposed autosomal recessive mode of inheritance. Seven of the previously reported cases were females, 14 were males and in one, the sex was undetermined. Chromosomal studies in one patient showed no abnormality (Freeman et al., 1974), but Appelt et al. (1966) have reported one female patient with a single sex chromatin body. (Chromosomal studies were not done in our case.) It would appear that whatever the genetic abnormal-

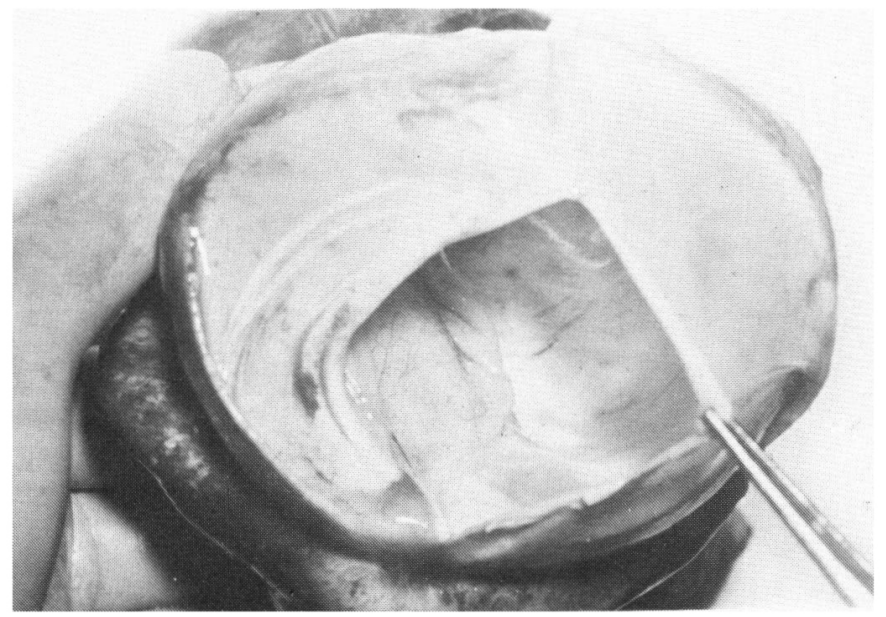

Figure 3-Photograph of the head with the dura opened and the cyst ruptured. The dura is held with a pair of forceps and the collapsed membranous wall of the cyst is seen in the floor of the intracranial cavity after it was emptied of its content.

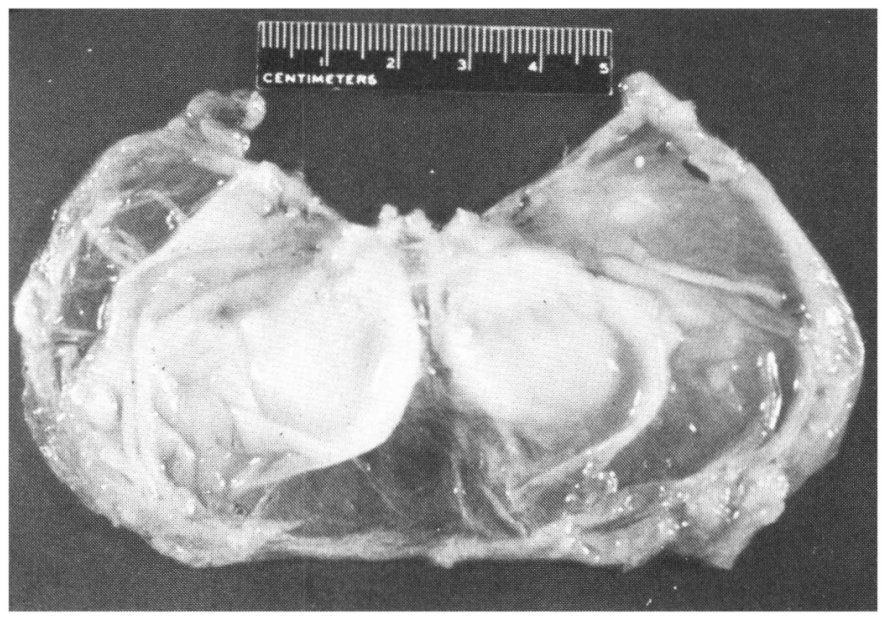

Figure 4-Photograph of the hypoplastic brain. The thicker, more central areas are the region of the basal ganglia. 


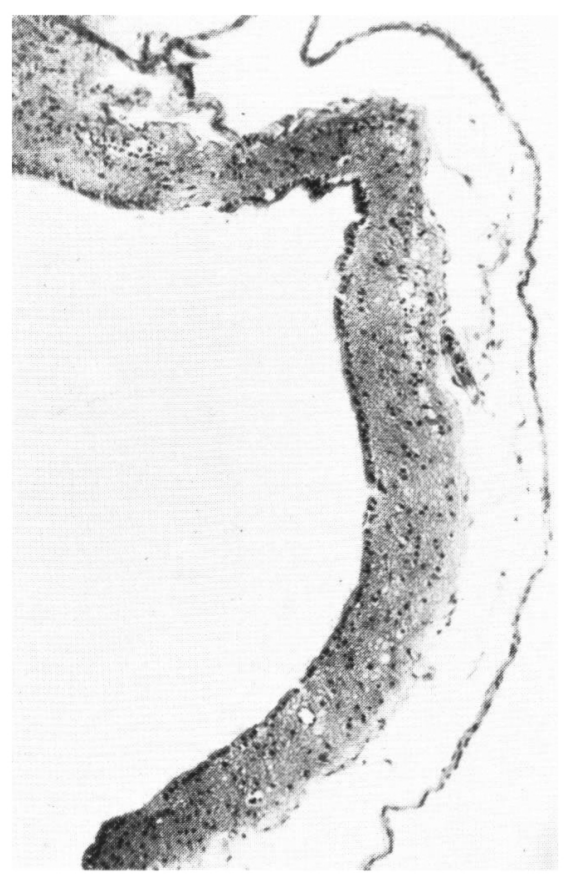

Figure 5-Photomicrograph of a coronal section of the hypoplastic brain. An outer leptomenix and an inner ependyma are seen. The intervening tissue is poorly differentiated. H \& E x 50

ity is, it is so strategically placed as to cause multisystem anomalies. They were all of low birth weight, and the few that survived for more than a few weeks failed to thrive. Of the 22 pre- viously reported cases, six were stillborn, six survived for only a few days, two for less than one year, and one for two years. Only three were alive at the the time of report (Freeman et al., 1974). They were aged 11 years, eight years and two months.

There is very little information about the nervous system in these patients. The longest survivor of this syndrome was described as semiconscious, responding quietly to his parents and violently to unfamiliar examiners, but not communicating otherwise (Freeman et al., 1974). This status did not change significantly even at the age of eleven years. He was also brachycephalic. One of the patients, who was stillborn, had a large frontal encephalocele containing most of the cerebrum, two others had hydrocephalus, and one had spina bifida (Freeman et al., 1974).

Autopsy was performed in six cases. In Case 2 of Freeman et al. (1974), the only abnormality related to the central nervous system was dilated veins over the anterior fontanelle. The autopsy of their Case 3 showed encephalocele and a short neck. The brain was not described. Spina bifida, and hydrocephalus were mentioned in their Cases 4 and 5 respectively. Appelt et al. (1966) mentioned hydrocephalus in their case. It is our impression that these patients all have maldevelopment of the nervous system, resulting in their mental retardation. This seems to vary from mere hydrocephalus as in the cases of Freeman et a. (1974) to hydranencephaly, as in our patient.

\section{ACKNOWLEDGEMENTS}

The authors are grateful to Dr. E. W. Schmidt, the attending obstetrician in charge of this case, for permission to report the case.

\section{REFERENCES}

APPELT, H., GERKEN. H., and LENZ, W (1966). Tetraphokomelie mit LippenKiefer-Gaumenspalte und Clitoreshypertrophie-ein Syndrom. Pädiatrie und Pädalogie. 2,119-124.

FREEMAN, M. V. R., GERMAN, J., WILLIAMS, D. W., SCHIMKE, R. M., TEMTAMY, S. A., and VACHIER, E. (1974). The Roberts Syndrome. Clin. Genet. 5: 1-16.

HOLMES, L. B., MOSER, H. W, HALL.DORSON, S.. MACK, C.. PANT. S. S., MATZILEVICH. B. (1972). Mental Retardation. The MacMillan Company. New York. Pages 344 and 345.

ROBERTS, J. B. (1919). A child with double cleft of lip and palate, protrusion of the intermaxillary portion of the upper jaw and imperfect development of the bones of the four extremities. Ann. Surg. 70, 252. 